\title{
SELEKSI INDUK KAMBING SABURAI BERDASARKAN NILAI MOST PROBABLE PRODUCING ABILITY BOBOT LAHIR DAN BOBOT SAPIH
}

\author{
Saburai Does Selection Based on Most Probable Producing Ability of Birth Weight \\ and Weaning Weight
}

\author{
Arif Gian Pratama ${ }^{1}$, Akhmad Dakhlan $^{2 *}$, Sulastri $^{2}$, Muhammad Dima Iqbal Hamdani ${ }^{2}$ \\ ${ }^{1}$ Alumni of Department of Animal Husbandry, Faculty of Agriculture, University of Lampung \\ ${ }^{2}$ Department of Animal Husbandry, Faculty of Agriculture, University of Lampung \\ Jl. Prof. Soemantri Brojonegoro No.1 Bandar Lampung 35145 \\ *E-mail: akhmad.dakhlan@ @p.unila.ac.id
}

Submitted : February 4, $2020 \quad$ Accepted : March 27, 2020

\begin{abstract}
ABSTRAK
Estimasi nilai Most Probable Producing Ability (MPPA) induk kambing Saburai berdasarkan kinerja keturunannya sangat penting dalam pemilihan induk kambing. Penelitian ini dilakukan untuk memilih kinerja induk kambing Saburai terbaik berdasarkan nilai MPPA menggunakan kinerja berat lahir (BL) dan berat sapih (BS) anak kambing di Unit Pelaksana Teknis Daerah (UPTD) Pusat Pembibitan Kambing, Kecamatan Gedongtataan, Kabupaten Pesawaran, Provinsi Lampung. Penelitian ini menggunakan metode survei yang dilakukan pada April-Juni 2019. Dua puluh lima induk kambing Saburai menghasilkan 34 anak pada paritas pertama dan 33 anak pada paritas kedua digunakan dalam penelitian ini. Data BL dan BS disesuaikan terhadap jenis kelamin jantan, tipe jenis kelahiran tunggal, dan umur induk. Nilai ripitabilitas diestimasi menggunakan metode korelasi antar kelas dan digunakan untuk menghitung nilai MPPA. Hasil penelitian menunjukkan bahwa rata-rata BL anak kambing pada paritas pertama dan kedua, masing-masing adalah 3,09 $\pm 0,42 \mathrm{~kg}$ dan 3,28 $\pm 0,54 \mathrm{~kg}$, sedangkan rata-rata BS pada paritas pertama dan kedua, masing-masing adalah $17,20 \pm 1,69 \mathrm{~kg}$ dan 17,36 $\pm 2,24 \mathrm{~kg}$. Nilai ripitabilitas yang didapat untuk BL dan BS, masing-masing adalah 0,49 $\pm 0,08$ dan 0,55 $\pm 0,06$. Rata-rata nilai MPPA untuk BL dan BS, masing-masing adalah 3,19 $\pm 0,27 \mathrm{~kg}$ dan 17,28 $\pm 1,23 \mathrm{~kg}$. Enam induk kambing Saburai (B2, B1, C1, A3, D3, dan C8) memiliki nilai MPPA BL dan BS lebih tinggi dari rata-rata nilai MPPA populasi. Keenam induk ini sebaiknya dipertahankan dalam populasi untuk meningkatkan mutu genetik kambing Saburai.
\end{abstract}

Kata kunci: Berat lahir, Berat sapih, Induk Kambing Saburai, Nilai MPPA, Ripitabilitas.

\section{ABSTRACT}

Most Probable Producing Ability (MPPA) estimation based on offsprings performance is very important in goat selection. This research was conducted to select the best Saburai does based on their $M P P A$ using their kid's birth weight $(B W)$ and weaning weight $(W W)$ performances in the Regional Technical Implementation Unit of Goat Breeding Centers, Gedongtataan Subdistrict, Pesawaran Regency, Lampung Province. This study used a survey method which was conducted in April-June 2019. Twenty-five Saburai does generating 34 kids at first parity and 33 kids at second parity were used in this study. Data of $B W$ and $W W$ were adjusted for male sex, single birth type, and dam age. Repeatability estimate was estimated using interclass correlation methods and these values were used to calculate MPPA values. The result showed that the average of $B W$ at first and second parity was $3.09 \pm 0.42 \mathrm{~kg}$ and $3.28 \pm 0.54 \mathrm{~kg}$, respectively, while the average of $W W$ at first and second parity was $17.20 \pm 1.69 \mathrm{~kg}$ and $17.36 \pm 2.24 \mathrm{~kg}$, respectively. Repeatability estimates of $B W$ and $W W$ were $0.49 \pm 0.08$ and $0.55 \pm 0.06$, respectively. The average of MPPA value of $B W$ and $W W$ were $3.19 \pm 0,27 \mathrm{~kg}$ and $17.28 \pm 1.23 \mathrm{~kg}$, respectively. There were six Saburai does (B2, B1, C1, A3, D3, and C8) which had MPPA value of both $B W$ and WW higher than the average MPPA value of the population. These six Saburai does should be maintained in the population to improve the genetics of Saburai goat.

Keywords : Birth weight, MPPA value, Repeatability, Saburai does, Weaning weight. 


\section{PENDAHULUAN}

Provinsi Lampung merupakan provinsi dengan populasi kambing terbanyak di Pulau Sumatera. Populasi kambing pada 2018 mencapai 1.386.009 ekor lebih tinggi daripada Sumatera Utara (908.880 ekor), Aceh (658.613 ekor), Jambi (576.340 ekor), Sumatera Selatan (377.976 ekor), Bengkulu (299.501 ekor), Sumatera Barat (258.625 ekor) dan Riau (210.987 ekor) sedangkan populasi kambing di provinsi lain di Pulau Sumatera sangat rendah, yaitu Kepulauan Riau sebanyak 31.720 ekor dan Kepulauan Bangka Belitung sebanyak 5.608 ekor (Badan Pusat Statistik, 2019).

Tingginya populasi kambing di Provinsi Lampung merupakan hasil kinerja peternak dan Pemerintah Daerah Provinsi Lampung yang memiliki program pegembangan ternak kambing yang baik. Peternakan kambing Peranakan Etawah (PE) di Kabupaten Pesawaran dan kambing Saburai di Kabupaten Tanggamus merupakan dua dari beberapa wilayah yang perkembangan ternak kambingnya cukup pesat. Pemerintah Daerah Provinsi Lampung menunjuk Unit Pelaksana Teknis Daerah Balai Pembibitan Ternak Kambing (UPTD BPTK) Negeri Sakti, Provinsi Lampung untuk mengembangkan bibit kambing. Salah satu bibit yang dikembangkan adalah kambing Saburai.

Kambing Saburai merupakan kambing tipe pedaging hasil persilangan secara grading up antara kambing Boer jantan dengan kambing PE betina dengan komposisi darah $75 \%$ kambing Boer dan 25\% kambing PE. Pertumbuhan populasi kambing Saburai terus meningkat sehingga ditetapkan sebagai sumberdaya genetik lokal Provinsi Lampung berdasarkan Keputusan Menteri Pertanian Republik Indonesia Nomor 359/Kpts/PK.040/6/2015 (Kementrian Pertanian, 2015).

Peningkatan produktivitas kambing Saburai diperlukan program pemuliaan yang terus menerus yang salah satunya adalah seleksi induk. Induk kambing Saburai yang baik terlihat dari kemampuannya dalam menghasilkan anak dengan bobot lahir dan bobot sapih yang tinggi dan stabil pada setiap paritas. Hal itu dapat dilihat dari nilai ripitabiitas dan nilai MPPA induk kambing, dimana semakin tinggi nilai MPPA induk semakin produktif induk tersebut. Estimasi MPPA sangat penting untuk seleksi induk berdasarkan performan anak-anaknya (Said et al., 2016; Raoof, 2018) karena dapat mencerminkan produktivitas induk yang diseleksi. Seleksi induk kambing Saburai dimaksudkan untuk memilih kambing yang memiliki kemampuan tersebut berdasarkan nilai MPPA. Evaluasi induk kambing Saburai di UPTD BPTK Negeri Sakti, Provinsi Lampung belum dilakukan. Penelitian ini dilakukan untuk menyeleksi induk kambing berdasarkan nilai MPPA bobot lahir dan bobot sapih kambing Saburai di UPTD BPTK Negeri Sakti, Provinsi Lampung. Dengan diketahuinya nilai MPPA, induk-induk kambing diharapkan dapat membantu UPTD dalam meningkatkan mutu genetik kambing Saburai dimasa yang akan datang.

\section{MATERI DAN METODE}

\section{Materi}

Penelitian ini dilaksanakan di UPTD BPTK Negeri Sakti Provinsi Lampung. Rekording 25 ekor induk kambing Saburai yang telah menghasilkan cempe sebanyak 34 ekor dan 33 ekor, masing-masing pada paritas pertama dan kedua, digunakan dalam penelitian ini. Rekording meliputi umur induk pada waktu melahirkan, bobot lahir dan bobot sapih cempe, umur penyapihan, dan jenis kelamin cempe. Sebagai gambaran, UPTD BPTK Negeri Sakti berada di wilayah Kecamatan Gedung Tataan Kabupaten Peswaran yaitu pada posisi $5^{\circ} 10^{\prime}-5^{\circ} 50^{\prime}$ Bujur Timur dan antara $105^{\circ}-105^{\circ} 20^{\prime}$ Lintang Selatan. Curah hujan rata-rata di wilayah ini adalah 185,3 $\mathrm{mm} /$ bulan atau berkisar $2.264-2.868 \mathrm{~mm} /$ tahun dengan hari hujan 90-176 hari/tahun, dan suhu rata-rata $26,8^{\circ} \mathrm{C}$ serta kelembapan $81,08 \%$. Desa Negeri Sakti terletak pada ketinggian 142 meter dari permukaan laut.

\section{Metode}

Penelitian ini menggunakan metode survei dengan purposive sampling. Data yang digunakan berupa data bobot lahir (BL) dan bobot sapih (BS) cempe yang diperoleh dari 2017-2019. Data BL dan BS dilakukan penyesuian (koreksi) terhadap umur induk (faktor koreksi umur induk/FKUI), tipe kelahiran (faktor koreksi tipe kelahiran/FKTL), jenis kelamin (faktor koreksi jenis kelamin/FKJK) dan umur sapih (US) 4 bulan atau 120 hari. Data bobot lahir terkoreksi (BLT) menggunakan rumus:

$$
\mathrm{BLT}=(\mathrm{BL})(\mathrm{FKJK})(\mathrm{FKTL})
$$

$$
\begin{aligned}
& \multicolumn{2}{l}{\text { Keterangan: }} \\
& \text { BLT } \text { bobot lahir terkoreksi } \\
& \text { BL }=\text { bobot lahir } \\
& \text { FKJK }=\text { faktor koreksi jenis kelamin } \\
& \text { FKTL }=\text { faktor koreksi tipe lahir }
\end{aligned}
$$


Data bobot sapih terkoreksi (BST) dihitung dengan rumus sesuai rekomendasi Hardjosubroto (1994) sebagai berikut:

$\mathrm{BST}=\left(\mathrm{BL}+\left[\frac{\mathrm{BS}-\mathrm{BL}}{\mathrm{US}}\right][120]\right)(\mathrm{FKJK})(\mathrm{FKTL})(\mathrm{FKUI})$

Keterangan:

BST $=$ bobot sapih terkoreksi

BL = bobot lahir

BS = bobot sapih

US = umur sapih

FKJK = faktor koreksi jenis kelamin

FKTL = faktor koreksi tipe lahir

FKUI $=$ faktor koreksi umur induk

Nilai ripitabilitas (r) untuk $\mathrm{BL}$ dan $\mathrm{BS}$ diestimasi dengan metode korelasi antarkelas (interclass correlation method) dengan rumus sesuai rekomendasi Hardjosubroto (1994) sebagai berikut:

$$
r=\frac{\sum X Y-\left(\left(\sum X\right)\left(\sum Y\right) / n\right)}{\sqrt{\left(\sum X^{2}-\left(\sum X\right)^{2} / n\right)\left(\sum Y^{2}-\left(\sum Y\right)^{2} / n\right)}}
$$

Keterangan:

$$
\begin{aligned}
& \mathrm{r}=\text { nilai ripitabilitas } \\
& \mathrm{X}=\text { bobot lahir/bobot sapih anak kambing } \\
& \text { paritas pertama } \\
& \mathrm{Y}=\text { bobot lahir/bobot sapih anak kambing } \\
& \text { paritas kedua } \\
& \mathrm{n} \quad=\text { jumlah induk }
\end{aligned}
$$

Nilai ripitabilitas yang telah diperoleh digunakan untuk mengestimasi nilai MPPA induk, dimana nilai MPPA dihitung dengan rumus sesuai rekomendasi Hardjosubroto (1994) sebagai berikut:

$$
\mathrm{MPPA}=\left(\frac{\mathrm{nr}}{1+(\mathrm{n}-1) \mathrm{r}}\right)(\overline{\mathrm{P}}-\overline{\overline{\mathrm{P}}})+\overline{\overline{\mathrm{P}}}
$$

$$
\begin{aligned}
& \text { Keterangan: } \\
& \text { MPPA = Most Probable Producing Ability } \\
& \text { (kg) } \\
& \mathrm{n} \quad=\text { jumlah paritas } \\
& \mathrm{r}=\text { ripitabilitas bobot lahir/bobot } \\
& \text { sapih } \\
& \overline{\mathrm{P}} \quad=\text { rata-rata bobot lahir/bobot sapih } \\
& \text { anak per induk } \\
& \overline{\overline{\mathrm{P}}} \quad=\text { rata-rata bobot lahir/bobot sapih } \\
& \text { populasi. }
\end{aligned}
$$

Nilai MPPA bobot lahir dan bobot sapih masing-masing induk diurutkan untuk mengetahui induk dengan nilai MPPA tertinggi sampai terendah. Seleksi induk kambing didasarkan nilai MPPA tertinggi.

\section{HASIL DAN PEMBAHASAN}

\section{Bobot Lahir dan Bobot Sapih Kambing Saburai}

Bobot lahir dan bobot sapih kambing Saburai pada paritas pertama dan kedua disajikan pada Tabel 1. Rata-rata bobot lahir dan bobot sapih cempe pada paritas kedua cenderung lebih tinggi daripada paritas pertama, meskipun secara statistik tidak nyata $(\mathrm{P} \geq 0,05)$ perbedaannya. Hal tersebut mungkin disebabkan oleh faktor umur induk yang lebih tua dimana organ-organ tubuh kambing lebih dewasa sehingga induk yang lebih

\begin{tabular}{|c|c|c|}
\hline $\begin{array}{c}\text { Performa } \\
\text { (Performance })\end{array}$ & $\begin{array}{c}\text { Paritas pertama } \\
\text { (First parity) }\end{array}$ & $\begin{array}{l}\text { Paritas kedua } \\
\text { (Second parity) }\end{array}$ \\
\hline Bobot lahir & $3,09 \pm 0,42$ & $3,28 \pm 0,54$ \\
\hline Bobot sapih & $17,20 \pm 1,69$ & $17,36 \pm 2,24$ \\
\hline Umur induk saat melahirkan (bulan) & $28,88 \pm 5,40$ & $37,56 \pm 5,68$ \\
\hline Umur sapih (hari) & $105,84 \pm 8,66$ & $102,04 \pm 7,93$ \\
\hline Jumlah kelahiran tunggal (ekor) & 16 & 17 \\
\hline Jumlah kelahiran kembar dua (ekor) & 9 & 8 \\
\hline
\end{tabular}
tua lebih mampu mendistribusikan nutrisi yang diperolehnya untuk pertumbuhan fetus yang dikandungnya. Bobot lahir dan bobot sapih hasil penelitian ini lebih tinggi daripada kambing Boerawa (kambing Boer 50\% dan kambing Peranakan Ettawa/PE 50\%), kambing PE, kambing Boerka (50 \% kambing Boer dan 50\% kambing Kacang) dan kambing Kacang dengan bobot lahir masing-masing 2,91 kg, 2,36 kg, 2,43 $\mathrm{kg}$ dan $1,87 \mathrm{~kg}$ (Harris et al., 2009). Penelitian ini relatif sama jika dibandingkan dengan berat lahir kambing Saburai dalam kondisi pemeliharaan petani di Kecamatan Gisting $(3,3 \pm 0,4 \mathrm{~kg})$ dan Kecamatan Sumberejo (3,1 \pm 0,3 kg), Kabupaten Tanggamus (Adhianto et al., 2017).

Tabel 1. Bobot lahir dan bobot sapih kambing Saburai pada paritas pertama dan paritas kedua (Birth weight and weaning weight of Saburai goat at first and second parity) 
Menurut Jimenez-Badillo et al. (2009), peningkatan bobot badan anak kambing seiring dengan meningkatnya paritas induk yang disebabkan oleh perkembangan proses fisiologis. Menurut Zhang et al. (2009), perkembangan uterus semakin baik dengan semakin meningkatnya umur induk sehingga semakin tua umur induk akan menghasilkan anak dengan bobot lahir yang lebih tinggi daripada bobot lahir anak yang dilahirkan dari induk pada umur lebih muda.Rata-rata umur induk pada penelitian ini adalah $28,8 \pm 5,4$ bulan pada paritas pertama dan pada paritas kedua rata-rata umur 37,56 $\pm 5,68$ bulan. Hasil penelitian ini sesuai dengan laporan Sodiq (2012) bahwa umur induk berpengaruh terhadap bobot lahir dan bobot sapih. Induk berumur 5-6 tahun menghasilkan bobot lahir dan bobot sapih yang optimum. Bobot lahir anak kambing meningkat seiring dengan meningkatnya paritas dari pertama sampai keempat. Sebagai contoh bobot lahir anak kambing jantan kelahiran tunggal yang dilahirkan induk berumur satu tahun adalah $3,19 \pm 0,09 \mathrm{~kg}$, umur 2 tahun $3,89 \pm 0,18$ $\mathrm{kg}$, umur tiga tahun $4,19 \pm 0,14 \mathrm{~kg}$, umur empat tahun 4,24 $\pm 0,15 \mathrm{~kg}$, dan umur lima dan enam tahun 4,25 \pm 0,12 kg (Sodiq, 2012).

Bobot sapih (umur 3 bulan) kambing Saburai dalam penelitian ini lebih tinggi dibandingkan kambing Boerawa dan kambing PE dengan bobot sapih, masing-masing 14,28 $\pm 0,71$ $\mathrm{kg}$ dan 12,93 $\pm 0,56 \mathrm{~kg}$ (Sulastri dan Dakhlan, 2006), namun hasil penelitian saat ini relatif sama dengan hasil penelitian Dakhlan et al. (2009) yang melaporkan bahwa bobot sapih kambing Boerawa dan kambing PE yang dipelihara secara tradisional masing-masing adalah $18,40 \mathrm{~kg}$ dan $16,81 \mathrm{~kg}$, namun lebih rendah bila dibandingkan dengan bobot sapih kambing dengan pemeliharaan rasional/intensif dengan penambahan konsentrat yaitu masing-masing $22,95 \mathrm{~kg}$ dan $18,06 \mathrm{~kg}$.

Estimasi nilai ripitabilitas bobot lahir dan bobot sapih kambing Saburai
Nilai ripitabilitas bobot lahir dan bobot sapih kambing Saburai hasil penelitian ini masing-masing $0,49 \pm 0,08$ dan $0,55 \pm 0,06$ (Tabel 2). Ripitabilitas bobot lahir kambing Saburai 0,49 berarti bahwa perbedaan atau keragaman bobot lahir kambing Saburai, 49,00\% disebabkan oleh faktor genetik total dan lingkungan permanen, sedangkan sisanya $(51,00 \%)$ disebabkan oleh faktor lingkungan temporer. Demikian juga ripitabilitas bobot sapih kambing Saburai 0,55 menunjukkan bahwa keragaman bobot sapih kambing Saburai sebanyak 55,00\% disebabkan oleh faktor keragaman genetik total dan lingkungan permanen, sedangkan $45,00 \%$ disebabkan oleh keragaman lingkungan temporer.

Nilai ripitabilitas hasil penelitian ini termasuk kategori tinggi menurut Hardjosubroto (1994) dan Sulastri et al. (2020) yakni 0,0-0,2 (rendah), 0,2-0,4 (sedang), dan > 0,4 (tinggi). Berdasarkan hasil estimasi tersebut, maka pemilihan calon tetua atau penentuan kambing betina yang layak untuk dipertahankan sebagai tetua dalam populasi dapat dilakukan melalui seleksi individu.

Warwick et al. (1990) dan Sulastri (2014) melaporkan bahwa nilai ripitabilitas performa tinggi menunjukkan kemampuan ternak dalam menghasilkan anak dengan performa keragaman yang rendah atau performa yang hampir sama pada paritas pertama dan paritas selanjutnya. Nilai ripitabilitas hasil penelitian ini lebih rendah dari hasil penelitian Isngatirah (2018) yang melaporkan bahwa nilai ripitabilitas bobot sapih kambing Saburai di kabupaten Tanggamus yang diestimasi dengan metode korelasi antarkelas adalah 0,76 di Kecamatan Sumberejo dan 0,59 di Kecamatan Gisting, namun hasil penelitian ini lebih besar dibandingkan dengan hasil penelitian Sulastri et al. (2016) yang melaporkan bahwa estimasi ripitabilitas dengan metode interclass correlation pada bobot lahir dan bobot sapih kambing Saburai di Kecamatan Sumberejo, Kabupaten Tanggamus masing-masing 0,12 \pm 0,05 dan $0,16 \pm 0,07$.

Tabel 2. Nilai ripitabilitas dan MPPA bobot lahir dan bobot sapih kambing Saburai (Repeatability estimate and MPPA value of birth weight and weaning weight of Saburai goat)

\begin{tabular}{lcc}
\hline $\begin{array}{c}\text { Peubah } \\
\text { (Variable })\end{array}$ & \multicolumn{2}{c}{ Performa (Performance) } \\
\cline { 2 - 3 } & $\begin{array}{c}\text { Bobot lahir } \mathbf{( k g )} \\
\text { (Birth weight, } \mathbf{k g})\end{array}$ & $\begin{array}{c}\text { Bobot sapih } \mathbf{( k g )} \\
\text { (Weaning weight, } \boldsymbol{k g})\end{array}$ \\
\hline Ripitabilitas & 0,49 & 0,55 \\
Rata-rata MPPA & 3,19 & 17,28 \\
Standar Deviasi & 0,27 & 1,23 \\
MPPA tertingi & 3,56 & 20,10 \\
MPPA terendah & 2,59 & 14,75 \\
\hline
\end{tabular}




\section{Nilai MPPA Bobot Lahir dan Bobot Sapih Kambing Saburai}

Rata-rata nilai MPPA bobot lahir dan bobot sapih kambing Saburai hasil penelitian ini disajikan pada Tabel 2. Rata-rata nilai MPPA BL dan BS pada penelitian ini berturut-turut adalah $3,19 \pm 0,27 \mathrm{~kg}$ dan $17,28 \pm 1,23 \mathrm{~kg}$. Nilai MPPA tersebut menunjukkan kemampuan induk dalam menghasilkan anak pada masa yang akan datang adalah sebesar 3,19 $\pm 0,27 \mathrm{~kg}$ untuk bobot lahir dan $17,28 \pm 1,23 \mathrm{~kg}$ untuk bobot sapih. Nilai MPPA ini yang merupakan cerminan kemampuan induk diharapkan diwariskan pada generasi keturunannya. Hasil penelitian ini sedikit lebih tinggi dibandingkan dengan hasil penelitian Isngatirah (2018) dan Adhianto et al. (2019) bahwa rata-rata MPPA bobot sapih kambing Saburai di Kecamatan Sumberejo adalah 16,75 $\pm 3,48 \mathrm{~kg}$ dan Kecamatan Gisting sebesar $16,93 \pm 2,15 \mathrm{~kg}$. Perbedaan ini nilai MPPA BL dan BS kambing Saburai hasil penelitian ini dipengaruhi oleh nilai ripitabilitas, rata-rata $\mathrm{BL}$ atau $\mathrm{BS}$ cempe per induk, dan ratarata $\mathrm{BL}$ atau $\mathrm{BS}$ populasi.

Kambing-kambing betina di lokasi penelitian yang memiliki nilai MPPA bobot lahir dan MPPA bobot sapih lebih tinggi daripada ratarata MPPA bobot lahir dan bobot sapih populasi dapat dipilih sebagai kambing betina yang layak dipertahankan sebagai tetua pada periode produksi berikutnya yakni dapat digunakan dalam wilayah pembiakan untuk dikembangbiakkan lebih lanjut. Berdasarkan hasil penelitian ini terdapat 14 ekor kambing Saburai dengan MPPA bobot lahir yang lebih tinggi daripada rata-rata MPPA bobot lahir populasi. Kambing-kambing betina yang memiliki nilai MPPA bobot lahir lebih tinggi daripada rata-rata MPPA populasi disajikan pada Tabel 3 dan sebaran nilai MPPA bobot lahir bagi seluruh induk kambing Saburai dalam bentuk histogram disajikan pada Gambar 1 .

Nilai MPPA bobot sapih kambing Saburai hasil penelitian ini lebih rendah daripada hasil penelitian Sulastri (2010) yang melaporkan bahwa rata-rata MPPA bobot sapih kambing Saburai betina di Kecamatan Sumberejo, Kabupaten Tanggamus sebesar 22,57 kg dan hasil penelitian Rinaldi et al. (2014) pada kambing PE dengan nilai MPPA bobot sapih 20,18 \pm 0,64 di Kecamatan Metro Selatan dan 21,10 \pm 0,85 di Kecamatan Metro Barat. Nilai MPPA hasil penelitian ini juga lebih rendah dari nilai MPPA Boerawa Grade-1 dan Grade-2 (Yuwanda et al., 2016) yaitu masing-masing $20,57 \pm 0,50$ dan $22,70 \pm 0,53$. Namun demikian nilai MPPA hasil penelitian ini lebih tinggi daripada hasil penelitian Isngatirah (2018) yaitu $16,59 \mathrm{~kg}$ di Kecamatan Sumberejo dan 16,93 kg di Kecamatan Gisting. Perbedaan nilai MPPA hasil penelitian ini dengan hasil penelitian sebelumnya disebabkan oleh perbedaan genetik kambing yang diamati, perbedaan kondisi lingkungan yang memengaruhi kualitas pakan sehingga menghasilkan performa pertumbuhan yang berbeda. Hal ini didukung oleh pernyataan Harjosubroto (1994) yang menyatakan bahwa nilai MPPA dipengaruhi oleh nilai ripitabilitas, performa, frekuensi paritas dan rata-rata performa populasi.

Tabel 3. Nilai MPPA bobot lahir sepuluh induk kambing Saburai dengan nilai MPPA yang lebih tinggi daripada nilai MPPA rata-rata populasi (MPPA value of birth weight of ten Saburai does which were higher than the average MPPA of population)

\begin{tabular}{ccc}
\hline \hline $\begin{array}{c}\text { Peringkat } \\
\text { (Ranking) }\end{array}$ & $\begin{array}{c}\text { Kode ternak } \\
\text { (Animal code })\end{array}$ & $\begin{array}{c}\text { Nilai MPPA bobot lahir (kg) } \\
(\text { MPPA value of birth weight, } k g)\end{array}$ \\
\hline 1 & B2 & 3,62 \\
2 & A5 & 3,57 \\
3 & B1 & 3,56 \\
4 & C1 & 3,56 \\
5 & A3 & 3,39 \\
6 & C11 & 3,39 \\
7 & A2 & 3,37 \\
8 & D3 & 3,35 \\
9 & C3 & 3,33 \\
10 & C8 & 3,29 \\
11 & C2 & 3,28 \\
12 & C5 & 3,28 \\
13 & C7 & 3,24 \\
14 & C4 & 3,23 \\
\hline
\end{tabular}



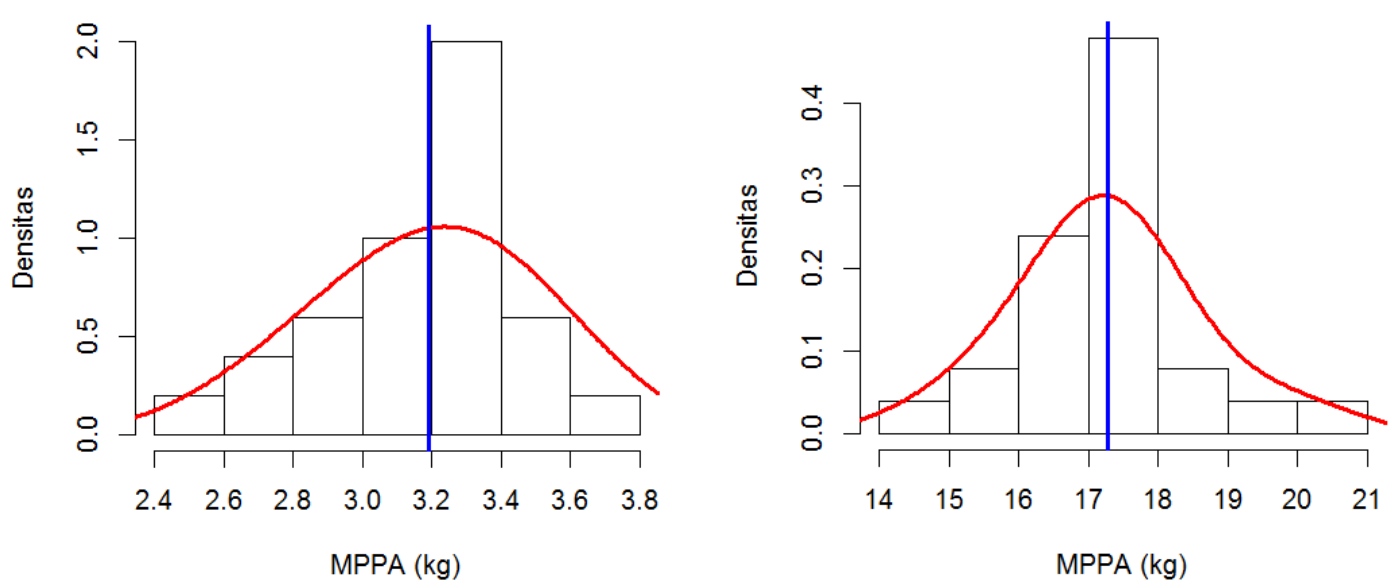

Gambar 1. Histogram nilai MPPA bobot lahir (kiri) dan bobot sapih (kanan) bagi induk kambing Saburai (Histogram of MPPA value of birth weight (left) and weaning weight (right) of Saburai does)

Induk dengan nilai MPPA bobot lahir dan MPPA bobot sapih tinggi pada penelitian ini disebabkan oleh tingginya nilai ripitabilitas bobot lahir dan bobot sapih anak yang dilahirkan pada setiap paritas. Induk dengan nilai MPPA tinggi diharapkan dapat mewariskan mutu genetik terbaiknya pada paritas selanjutnya yang menunjukan induk tersebut mampu menghasilkan anak (offspring) dengan bobot lahir dan bobot sapih yang tinggi pula. Induk yang memiliki nilai MPPA tinggi sebaiknya dipertahankan keberadaan dalam suatu populasi guna meningkatkan mutu genetik kambing berdasarkan sifat bobot lahir dan sapih yang tinggi.

Berdasarkan nilai MPPA bobot sapih terdapat 13 ekor kambing Saburai dengan nilai MPPA bobot sapih yang lebih tinggi daripada
MPPA bobot sapih populasi. Kambing-kambing betina yang memiliki nilai MPPA bobot sapih lebih tinggi daripada rata-rata disajikan pada Tabel 4 dan sebaran nilai MPPA bobot sapih dalam bentuk histogram disajikan pada Gambar 1 . Kambing Saburai betina dengan nilai MPPA bobot lahir yang tinggi tidak seluruhnya mencapai nilai MPPA bobot sapih yang tinggi, bahkan ada yang tidak melampaui rata-rata MPPA bobot sapih. Kambing dengan kode B2, B1, C1, A3, D3, dan C8 yang memiliki MPPA bobot lahir dan MPPA bobot sapih yang lebih tinggi dari ratarata. Kambing lainnya hanya memiliki MPPA bobot lahir saja atau MPPA bobot sapih saja yang tinggi. Hal tersebut disebabkan oleh perbedaan kemampuan anak kambing dalam berinteraksi dengan lingkungan.

Tabel 4. Kambing Saburai betina dengan nilai MPPA bobot sapih lebih tinggi daripada rata-rata (Saburai does with higher MPPA value than population average)

\begin{tabular}{ccc}
\hline $\begin{array}{c}\text { Peringkat } \\
\text { (Ranking) }\end{array}$ & $\begin{array}{c}\text { Kode ternak } \\
\text { (Animal code })\end{array}$ & $\begin{array}{c}\text { MPPA bobot sapih }(\mathrm{kg}) \\
(\text { MPPA of weaning weight, } \mathrm{kg})\end{array}$ \\
\hline 1 & A3 & 20,10 \\
2 & C10 & 19,90 \\
3 & C1 & 18,87 \\
4 & C4 & 18,33 \\
5 & D3 & 17,87 \\
6 & D1 & 17,85 \\
7 & C2 & 17,82 \\
8 & B1 & 17,55 \\
9 & C8 & 17,55 \\
10 & D2 & 17,53 \\
11 & B2 & 17,41 \\
12 & A4 & 17,39 \\
13 & D4 & 17,33 \\
\hline
\end{tabular}




\section{SIMPULAN}

\section{Simpulan}

Berdasarkan hasil penelitian dan pembahasan maka dapat disimpulkan bahwa nilai ripitabilitas bobot lahir $(0,49 \pm 0,08)$ dan ripitabilitas bobot sapih $(0,55 \pm 0,06)$ kambing Saburai betina termasuk kategori tinggi. Terdapat 6 ekor induk (B2, B1, C1, A3, D3, dan C8) yang memiliki nilai MPPA bobot lahir sekaligus MPPA bobot sapih yang lebih tinggi dari rata-rata nilai MPPA populasi yang sebaiknya dipertahankan dalam populasi. Jika seleksi direncanakan terhadap 50\% induk terbaik maka kriteria seleksi nilai MPPA bobot sapih dapat digunakan yaitu terdapat 13 ekor induk yang memiliki nilai MPPA bobot sapih terbaik.

\section{Saran}

Berdasarkan hasil penelitian ini dapat disarankan agar pihak UPTD PBTK Negeri Sakti melakukan estimasi parameter genetik secara periodik untuk meningkatkan akurasi pelaksanaan seleksi kambing Saburai betina.

\section{DAFTAR PUSTAKA}

Adhianto, K., Sulastri, M.D.I. Hamdani, D. Novriani, \& L. Yuliani. 2017. Performans Kambing Saburai Betina Di Wilayah Sumber Bibit Kabupaten Tanggamus Provinsi Lampung. J. Ilmu-Ilmu Peternakan 20(1): 9-16. https://onlinejournal.unja.ac.id/jiip/article/view/4057/2 988

Adhianto, K., T. Isngatirah, Sulastri, and M.D.I. Hamdani. 2019. Estimation of Repeatability Value of Weaning Weight and Most Probable Producing Ability (MPPA) of Saburai Doe in Tanggamus Regency. Buletin Peternakan (Bulletin of Animal Science) 43(4): 247-251.

Badan Pusat Statistik. 2019. Populasi Kambing Menurut Provinsi Tahun 2009-2018. https//www.bps.go.id. Diakses 18 Februari 2019.

Dakhlan, A., Sulastri, I. Damayanti, Budiyah, \& K. Kristianto. 2009. Does Productivity Index of Boerawa Does and Etawa Grade Does Fed by Traditional and Rational Foodstuff. Proceeding of The 1st International Seminar on Animal Industry "Sustainable Animal Production for Food Security and Safety", Faculty of Animal Science, Bogor Agricultural University, 23-24 November 2019.
Hardjosubroto, W. 1994. Aplikasi Pemuliabiakan Ternak di Lapangan. PT Grasindo. Jakarta.

Harris, I., A. Dakhlan, \& S. Suharyati. 2009. Performance of Grade-1 Kids as A Result of Grading-Up Between Local Goats and Boer Goats. Proceeding of The 1st International Seminar on Animal Industry "Sustainable Animal Production for Food Security and Safety", Faculty of Animal Science, Bogor Agricultural University, 23-24 November 2019.

Isngatirah, T. 2018. Estimasi Nilai Ripitabilitas Bobot Sapih dan Most Probable Producing Ability (MPPA) Kambing Saburai Betina di Kabupaten Tanggamus. Skripsi. Fakultas Pertanian. Universitas Lampung. Bandar Lampung.

Jimenez-Badillo, M.R., S. Rodrigues, C. Sanudo, and A. Teixeira. 2009. Non-genetic factors affecting live weight and daily gain weight in Serrana Transmontano kids. Small Ruminant Research 84: 125-128. https://doi.org/10.1016/j.smallrumres.200 9.06 .002

Kementrian Pertanian 2015. Keputusan Menteri Pertanian Republik Indonesia Nomor 359/Kpts/PK.040/6/2015 tentang Penetapan Rumpun Kambing Saburai. http://bibit.ditjenpkh.pertanian.go.id/sites/ default/files/Keputusan\%20Menteri\%20P ertanian\%20Nomor\%20359\%20Tahun\%2 02015\%20Tentang\%20Penetapan\%20Ru mpun\%20Kambing\%20Saburai.pdf. Diakses 7 April 2019.

Raoof, S.O. 2018. Most Probable Producing Ability (MPPA) of Daily Milk Production for Local Cows. Iraqi J. of Agr. Sci. 49(3):493-499.

Rinaldi, D., I. Harris, dan Novirzal. 2014. Perbandingan nilai Most Probable Producing Ability Kambing Ettawah antar Kecamatan Metro Selatan dan Metro Barat, Kota Metro. Jurnal Ilmiah Peternakan Terpadu 2(2):54-57.

Said, S., P.P. Agung, W.P.B. Putra, S. Anwar, A.S. Wulandari, and A. Sudiro. 2016. Estimation of Most Probable Producing Ability Value for Calf Birth's Performance in Sumba Ongole Cows. J. of the Indonesian Tropical Animal Agriculture 41(2):53-60. DOI: 10.14710/jitaa.41.2.5360

Sodiq, A. 2012. Non genetic factors affecting preweaning weight and growth rate of Ettawah Grade Goats. Media Peternakan. 35(1): 21-27. 
Sulastri \& A. Dakhlan. 2006. Comparison on Does Productivity Index between Boerawa and Ettawa Grade Goat at Campang Village, Gisting, Tanggamus. Proceeding of the $4^{\text {th }}$ ISTAP "Animal Production and Sustainable Agriculture in the Tropic, Faculty of Animal Science, Universitas Gadjah Mada, November 8-9, 2006.

Sulastri. 2010. Genetic potency of weaning weight of Boerawa F1, Backcross 1 and Backross 2 does at Village Breeding Centre, Tanggamus Regency, Lampung Province. Proceeding of The $5^{\text {th }}$ International Seminar on Tropical Animal Production, pp. $556-560$

Sulastri. 2014. Karakteristik Genetik Bangsabangsa Kambing di Provinsi Lampung. Disertasi. Program Pascasarjana Fakultas Peternakan. Universitas Gajah Mada. Yogyakarta

Sulastri, M.D.I. Hamdani, dan K. Adhianto. 2016. Penentuan Sistem Pemuliabiakan dalam Populasi Kambing Saburai untuk Meningkatkan Kinerja Pertumbuhannya J. Riset Agribisnis dan Peternakan. 1(1): 10-21.

Sulastri, M.D.I. Hamdani dan A. Dakhlan. 2020. Dasar Pemuliaan Ternak. Penerbit AURA CV. Anugrah Utama Raharja. Bandar Lampung.

Warwick, E.J., J.M. Astuti, dan W. Hardjosubroto. 1990. Pemuliaan Ternak. Gajah Mada University Press. Yogyakarta.

Yuwanda, F., Sulastri, dan M.D.I. Hamdani. 2016. Seleksi induk kambing Boerawa grade 1 dan 2 berdasarkan nilai Most Probable Producing Ability bobot anak umur 6 bulan. JIPT 4(1): 24-28

Zhang, C.Y., Y. Zhang, D.Q. Xu, X. Li, J. Su and L.G. Yang. 2009. Genetic and phenotypic parameter estimates for growth traits in Boer goat. Livestock Science 124(1-3): 66-71.

https://doi.org/10.1016/j.livsci.2008.12.0 $\underline{10}$ 